\title{
ANAPLASMOSIS IN ANIMALS
}

\author{
Karlsen, A., Vojtek, B., Mojžišová, J., Prokeš, M., Drážovská, M. \\ Department of Epizootiology, Parasitology and Protection of One's Health \\ University of Veterinary Medicine and Pharmacy in Košice, Komenského 73, 04181 Košice \\ Slovakia
}

monika.drazovska@uvlf.sk

\begin{abstract}
Anaplasmosis is a vector-borne, infectious and noncontagious disease. The disease is caused by various pathogens of the genus Anaplasma. The different species cause different types of anaplasmosis depending on which cells that are infected in the mammalian host. Anaplasmosis has a wide host range, including humans, and it is distributed worldwide. The zoonotic potential of some species is of great importance in regards to public health concerns. This review presents information about anaplasmosis in animals and its prevalence in Europe, and other countries in the world.
\end{abstract}

Key words: anaplasmosis; infectious disease; reemerging; vector-borne disease; zoonosis

\section{INTRODUCTION}

Anaplasmosis is caused by bacteria of the genus Anaplasma, order Rickettsiales which was formed after a merging of the families Anaplasmataceae and Rickettsiaceae
[17]. Anaplasma spp. contains several individual species including: Anaplasma phagocytophilum, Anaplasma platys, Anaplasma marginale, Anaplasma bovis, Anaplasma ovis, and Anaplasma centrale. A newly discovered species which has not yet been officially recognized as a separate species is named Anaplasma capra [45]. The zoonotic potential of the bacteria is of great importance in consideration of public health concerns [30]. Anaplasmosis is a vector-borne disease which is usually transmitted by ticks, but other mechanisms do also exist [50].

Bacteria in the Anaplasma spp. are obligate intracellular pathogens found inside vacuoles in the cytoplasm of the infected eukaryotic host cells. The mammalian host cells that become infected are variable depending on the species of Anaplasma spp., and includes granulocytes, erythrocytes, endothelial cells and platelets. The bacteria differ from other gram-negative bacteria by not having a cell wall which make them sensitive to mechanical stress. They are enveloped, but lack thickening of the leaflets and are without peptidoglycan layers or lipopolysaccharides (LPS) [30]. The bacteria replicate inside the host cell, forming microcolonies called morulae [45]. 
Anaplasma phagocytophilum is the causative agent of granulocytic anaplasmosis in horses, humans, canines and felines. In ruminants the disease is known as tick-borne fever [3]. Anaplasma platys cause infectious cyclic thrombocytopenia in dogs mainly. Individual cases have also been found in cats, humans and cattle. Although different strains of Anaplasma platys with variable pathogenicity have been detected [64], it is considered as a canine pathogen $[30,45]$. Anaplasma marginale cause the "classical" anaplasmosis called erythrocytic anaplasmosis in ruminants [45]. It is the cause of economic losses in the cattle industry. Anaplasma bovis, Anaplasma ovis and Anaplasma centrale are closely related to Anaplasma marginale, but typically cause a milder disease $[1,59]$. Anaplasma capra has been detected as an emerging bacterium which infects ruminants and humans [39]. S e o et al. [59] states that if this bacterium is determined to be pathogenic to humans and other animals, it may be an essential health risk.

Anaplasma spp. are commonly transmitted through ticks. The different Anaplasma spp. have different tick species for transmission. The most common genus of ticks that function as vectors is Ixodes spp. Other species include Dermacentor spp., Rhipicephalus spp., Hyalomma spp., and Haemaphysalis spp. [45]. For the tick to be infected and be able to transmit the pathogen, the tick needs to live in a habitat where there are mammals present that can serve as reservoirs for the Anaplasma spp. [18]. Biological transmission by ticks is the most common way of transmission of Anaplasma spp. In general, transmission of $A$. phagocytophilum by ticks starts within a few hours after attachment but establishment of infections was observed only when ticks attached for greater than 48 hours [26]. Furthermore, other mechanisms such as mechanically by biting flies and by blood-contaminated fomites, have also been recorded in A. phagocytophilum and A. marginale $[37,63]$. The wide variety of reservoir hosts of Anaplasma spp. varies with the species and the geographical location, but typically include wild ruminant species [42, 71]. Migrating birds that can carry long-range ticks may have an essential role in the spreading of the pathogen $[66,67]$.

The incubation period is in the range from 5 to 14 days. The clinical signs of diseases caused by Anaplasma spp. show a lot of similarities across the different species and infected hosts, although there are some variations both in what type of signs that occur, and in the degree of severity of the clinical signs. Diseases caused by Anaplasma spp. commonly cause non-specific febrile illness in the infected mammalian host. Acutely infected animals lose condition. The next most described clinical signs are distal limb oedema, a reluctance to move, inappetence, decreasing of milk production, loss of coordination and breathlessness. Ruminants that are infected with Anaplasma spp. tend to develop more severe disease. Death from infection by Anaplasma spp. has the highest occurrence in infected ruminants that develop a progressive disease $[5,37,54]$. In addition, ruminants become persistent carriers and reservoirs for Anaplasma spp. [42]. Horses, dogs, cats, and humans rarely succumb to the disease. In most cases, the diseases are self-limiting $[58,64]$. The severity of clinical signs tends to increase with the age of mammalian host infected with Anaplasma spp. [42, 58, 63]. The most common laboratory findings in diseases caused by Anaplasma spp. are thrombocytopenia, leukopenia, and anaemia [30]. When the pathogen comes in contact with the eukaryotic host cells, the pathogen adheres to the surface of the cell. It enters the cell by endocytosis and forms vacuoles within the cytoplasm of the host cells. Once inside the cells, they begin to replicate by binary fission after which the specific morulae is formed [30].

The epizootic history of the patient together with the clinical signs and laboratory findings is essential in confirming infection by Anaplasma spp. [18, 30]. The microscopic detection of the morulae in infected cells by Giemsa or Wright's staining is a fast and cost-effective diagnostic tool; PCR, IFA and ELISA are also commonly used [1, 30, 67].

Treatment of individuals with diseases caused by Anaplasma spp. depends on the severity. In individuals where the disease is commonly self-limiting, and the clinical signs are mild, the patient is usually left without any specific treatment. If the disease is more progressive, the typical treatment is antibiotics $[1,30,63,67]$. One should also have in mind that the intensive use of antibiotics increases the chance of microorganisms becoming resistant to treatment by antibiotics [37]. The most important preventive measure to avoid infection and spreading of Anaplasma spp. is tick control [1]. There are no current vaccines that are available against Anaplasma spp. except for Anaplasma marginale $[36,65]$. There have been some thoughts that recovery from the disease caused by A. phagocytophilum can provide immunity, but the period of protection is variable [1]. 
The aim of this study was to describe anaplasmosis in animals. This includes describing the different Anaplasma spp. with their characteristics, how they affect their host and their distribution worldwide. More cases have been reported during the latest years. This increase can be due to more transportation, climate changes and overall more research on the topic.

\section{OCCURRENCE OF ANAPLASMA SPP. IN EUROPE}

Anaplasmosis was detected in many European countries in various animal species with the prevalences ranging from $1.09 \%$ to $97.9 \%$ (Table 1 ). The variability of the prevalences could be due to the specific geographical area. High prevalence may be in association with the region having suitable environment for ticks, with appropriate vegetation and high mammalian host densities. The tick species $I$. rici$n u s$ is the main tick species in Europe, as well as a main vector for Anaplasma phagocytophilum transmission. Although in Europe several of the Anaplasma spp. are present and they vary in prevalence between the geographical areas, Anaplasma phagocytophilum was the most detected subspecies. However, the reason may also be the focus on this species due to its zoonotic potential. It has been identified in domestic species such as dogs, small mammals and horses but also in a variety of wild ruminants, as well as humans [54]. Ruminants have also been affected across Europe. A. phagocytophilum, A. marginale and A. ovis has been detected in Mediterranean countries, Central Europe and Sweden.

In general, higher prevalences seems to be in wildlife animals which could suggest the important role of wildlife as the possible reservoir. The prevalence may also vary with the different ecotypes or strains as showed in the study by $\mathrm{J}$ a h f a r i et al. [34]. As climates and habitats are changing, so does the distribution and movement of these wildlife species and the ticks with them. Norway function as a northern limit to the tick distribution due to the colder climate. In recent years there have been reports about the limit of ticks being pushed further north [54]. Tick-borne diseases such as anaplasmosis has been reported most frequently along the coast of Norway where there are high densities of ticks [31]. In Norway anaplasmosis is listed as a $\mathrm{C}$-disease in a ranging system of infectious diseases so there is no need to report the disease $[40,41,63]$. The variation in prevalence across Europe may be explained in association with a few main factors like variation in tick density, and density of vertebrate hosts. Furthermore, the disease is not reportable, meaning there is no database on the occurrences. It also presents with non-specific signs which can lead to it being overlooked. And in addition there has been a lack of attention to the disease, as it is not common to test for it, and there is a lack of specific diagnostic methods [24].

\section{OCCURRENCE OF ANAPLASMA SPP. IN OTHER COUNTRIES}

Anaplasmosis has spread throughout the world (Table 2). Other than Europe, anaplasmosis has been found in America, Africa, Asia, and Australia [1]. In the USA, the disease caused by $A$. phagocytophilum in humans is needed to be reported. The CDC shows an increase in reports from 2000 until 2017 [9]. Similarly, a significantly increasing trend for A. phagocytophilum seroprevalence in the canine population was recently observed by $\mathrm{D}$ e w a g e et al. [15] in the eastern USA. Furthermore, cats, cattle, rabbits and small mammal were investigated for the presence of Anaplasma spp.

New studies show a higher geographical range of the ticks with a corresponding increased number of cases of human granulocytic anaplasmosis in Canada. Although anaplasmosis is now considered as endemic only in several areas in Canada [11], U m i n s k i et al. [66] suggested that the disease should be made reportable. In Central and South America, A. platys in canines have been more frequent than in North America [30]. In recent years, there have been also more reports on Anaplasmosis spp. in South America [16, 48].

In Africa and the Middle East most of the Anaplasma spp. have been detected. However, mostly ruminants and ticks have been studied, especially in North Africa. Other domestic species, such as horses, dogs, and also humans have not been studied as much. This interest in studying ruminants may be due to the importance of livestock in the economy in these areas. The Anaplasma spp. that are studied include: A. marginale, A. ovis, A. bovis, and A. plat$y s$. Only small amount of information about $A$. phagocytophilum and its distribution in this area exist [8]. In Tunisia, studies there have been conducted on cattle with sev- 
Table 1. The prevalence of Anaplasma spp. in various animal host species in selected European countries $\mathrm{AO}-$ A. ovis; $\mathrm{AP}-$ A. phagocytophilum

\begin{tabular}{|c|c|c|c|c|c|}
\hline Country & $\begin{array}{c}\text { Anaplasma } \\
\text { species }\end{array}$ & Host species & No. tested & $\begin{array}{c}\text { Prevalence } \\
{[\%]}\end{array}$ & Source \\
\hline Austria & AP & Cattle & 140081 & 3.60 & [6] \\
\hline \multirow{4}{*}{ Czech Republic } & \multirow{4}{*}{ AP } & Cattle & 55 & 5.45 & \multirow{4}{*}[14,33,53]{} \\
\hline & & Sheep & 109 & 1.09 & \\
\hline & & \multirow[b]{2}{*}{ Horse } & 40 & 5.00 & \\
\hline & & & 96 & 73.00 & \\
\hline \multirow{6}{*}{ Hungary } & \multirow{6}{*}{ AP } & Dog & 1305 & 7.90 & \multirow{6}{*}[23,32]{} \\
\hline & & Fallow deer & 33 & 72.70 & \\
\hline & & Red deer & 48 & 97.90 & \\
\hline & & Roe deer & 65 & 60.00 & \\
\hline & & Mouflons & 16 & 6.30 & \\
\hline & & Wild boars & 17 & 39.20 & \\
\hline \multirow{2}{*}{ Germany } & \multirow{2}{*}{ AP } & \multirow{2}{*}{ Dog } & 111 & 43.20 & \multirow{2}{*}[35,38]{} \\
\hline & & & 522 & 43.00 & \\
\hline \multirow{11}{*}{ Italy } & \multirow{11}{*}{ AP } & & 20 & 15.00 & \multirow{11}{*}[3,19,20,21,51]{} \\
\hline & & & 135 & 17.03 & \\
\hline & & fluse & 160 & 25.62 & \\
\hline & & & 479 & 15.03 & \\
\hline & & Fallow deer & 67 & 46.26 & \\
\hline & & Red deer & 52 & 46.15 & \\
\hline & & Cattle & 137 & 16.78 & \\
\hline & & Sheep & 102 & 12.74 & \\
\hline & & Goats & 72 & 4.16 & \\
\hline & & \multirow{2}{*}{ Dog } & 1232 & 8.76 & \\
\hline & & & 40 & 7.50 & \\
\hline \multirow{5}{*}{ Norway } & \multirow{5}{*}{ AP } & Moose & 111 & 70.00 & \multirow{5}{*}[43,54,62]{} \\
\hline & & Red deer & 141 & 94.00 & \\
\hline & & 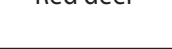 & 37 & 81.10 & \\
\hline & & \multirow{2}{*}{ Roe deer } & 28 & 82.00 & \\
\hline & & & 104 & 88.10 & \\
\hline Poland & $\mathrm{AP}$ & Horse & 76 & 1.3 & {$[60]$} \\
\hline \multirow{3}{*}{ Slovakia } & $\mathrm{AP}$ & Sheep & 202 & 16.16 & \multirow{3}{*}[14]{} \\
\hline & \multirow{2}{*}{$\mathrm{AO}$} & Sheep & 202 & 32.67 & \\
\hline & & Goat & 12 & 58.30 & \\
\hline \multirow{4}{*}{ Spain } & \multirow{4}{*}{$\mathrm{AP}$} & Cattle & 456 & 3.07 & \\
\hline & & Sheep & 389 & 0.51 & [A] \\
\hline & & Goat & 207 & 0.48 & {$[-]$} \\
\hline & & Horse & 46 & 6.52 & \\
\hline Sweden & AP & Sheep & 20 & 45.00 & [29] \\
\hline
\end{tabular}


Table 2. The prevalence of Anaplasma spp. in various animal host species in selected countries of the world

$\mathrm{AB}-A$. bovis; $\mathrm{AC}-$ A. centrale; $\mathrm{ACa}-\mathrm{A}$. capra; $\mathrm{AM}-A$. marginale; $\mathrm{AO}-A$. ovis; $\mathrm{AP}-$ A. phagocytophilum; $\mathrm{ASp}-\mathrm{A}$. spp.

\begin{tabular}{|c|c|c|c|c|c|}
\hline Country & $\begin{array}{c}\text { Anaplasma } \\
\text { species. }\end{array}$ & Host species & No. tested & $\begin{array}{c}\text { Prevalence } \\
{[\%]}\end{array}$ & Source \\
\hline \multirow{4}{*}{ Brazil } & \multirow{4}{*}{ AP } & \multirow{4}{*}{ Horse } & 98 & 17.40 & \multirow{4}{*}[16,47,55,56]{} \\
\hline & & & 91 & 12.00 & \\
\hline & & & 97 & 11.34 & \\
\hline & & & 20 & 65.00 & \\
\hline \multirow{13}{*}{ China } & \multirow{2}{*}{$A B$} & Dog & 243 & 4.10 & \multirow{13}{*}[12,52,70,71]{} \\
\hline & & Sheep & 435 & 24.40 & \\
\hline & \multirow{3}{*}{$\mathrm{ACa}$} & Sheep & 435 & 18.20 & \\
\hline & & Sheep & 1453 & 8.90 & \\
\hline & & Goat & 943 & 9.40 & \\
\hline & \multirow{2}{*}{$\mathrm{AO}$} & Dog & 243 & 6.20 & \\
\hline & & Sheep & 435 & 5.70 & \\
\hline & \multirow{6}{*}{ AP } & Sheep & 49 & 42.90 & \\
\hline & & Goat & 91 & 38.50 & \\
\hline & & Yak & 158 & 32.30 & \\
\hline & & Cattle yak & 20 & 35.00 & \\
\hline & & Dog & 243 & 0.40 & \\
\hline & & Sheep & 435 & 28.00 & \\
\hline \multirow{2}{*}{ Iran } & $A B$ & Cattle & 150 & 2.66 & \multirow{2}{*}[46,72]{} \\
\hline & $\mathrm{AM}, \mathrm{AO}$ & Sheep + goat & 370 & 27.50 & \\
\hline \multirow{2}{*}{ Canada } & \multirow{2}{*}{ AP } & Dog & 86251 & 0.19 & \multirow{2}{*}[57,68]{} \\
\hline & & Horse & 376 & 0.53 & \\
\hline Malaysia & AM & Cattle & 1045 & 72.60 & [49] \\
\hline \multirow{3}{*}{ Mexico } & ASp & Dog & 1706 & 9.90 & \multirow{3}{*}[44,48]{} \\
\hline & \multirow{2}{*}{ AP } & White-tailed deer & 25 & 20.00 & \\
\hline & & Mazama deer & 4 & 50.00 & \\
\hline \multirow{2}{*}{ Mongolia } & \multirow{2}{*}{$\mathrm{AO}$} & Sheep & 1179 & 69.00 & \multirow{2}{*}{ [22] } \\
\hline & & Goat & 871 & 71.30 & \\
\hline Nicaragua & ASp & Dog & 329 & 28.60 & [61] \\
\hline Niger & $\mathrm{AO}$ & Sheep & 33 & 69.70 & [13] \\
\hline \multirow{4}{*}{ South Korea } & & Cat & 33 & 18.20 & \multirow{4}{*}[10,59]{} \\
\hline & AP & Horse & 92 & 2.20 & \\
\hline & & Cattle & 129 & 0.80 & \\
\hline & $\mathrm{ACa}$ & Cattle & 1219 & 1.00 & \\
\hline \multirow{5}{*}{ Tunisia } & $A M$ & & 232 & 25.40 & \\
\hline & Mivi & & 328 & 24.70 & \\
\hline & $\mathrm{AC}$ & Cattle & 232 & 15.10 & {$[7,42]$} \\
\hline & $A B$ & & 232 & 3.90 & \\
\hline & AP & & 328 & 0.60 & \\
\hline Turkey & $\mathrm{AO}$ & Sheep + goat & 343 & 60.00 & [73] \\
\hline & $A D$ & Small mammal & 2121 & 15.24 & \\
\hline USA & $\mathrm{Ar}$ & Rabbits & 41 & 7.32 & \\
\hline התכל & & Cats & 175 & 9.70 & {$[2,25,27,69]$} \\
\hline & $A B$ & Rabbits & 41 & 36.58 & \\
\hline & AM & Cattle & 247 & 21.86 & \\
\hline
\end{tabular}


eral Anaplasma spp. including: A. marginale, A. centrale, A. bovis, and A. phagocytophilum [7, 42]. Several studies on sheep and goats have been conducted as well. Also, in Turkey, Iran and Niger, the breeding of small ruminants has significant economic importance. In these countries, A. ovis and A. marginale were detected in sheep and goat with variable prevalences $[13,72,73]$.

In Asia and Australia, there has been more reports in recent years. China has reported several different $A n$ aplasma spp. including the newly detected Anaplasma capra. A. capra has been detected in humans, sheep, and goats in China and in cattle in South Korea. The tick species Ixodes persulcatus is thought to be a possible vector for A. capra [39, 52, 59, 71]. A. phagocytophilum, A. ovis, A. bovis, and A. capra have been studied on several occasions across China. These Anaplasma spp. have been discovered in multiple host species $[12,52,70,71]$. They have been detected mainly in ruminants, probably due to the high impact of livestock production, but the occurrence of Anaplasma spp. were also investigated in dogs. Studies that were done on sheep, goat, and cattle in Mongolia and Malaysia show a relatively high prevalence of $A$. marginale $[22,49]$. In Australia, the only detected Anaplasma spp. has been on the strains of $A$. marginale, $A$. centrale, and A. plat$y s$, which have been introduced to the country by imported animals. However, they recently detected a unique A. bovis strains in native Australian ticks. This is genetically different from other variants worldwide [28].

\section{CONCLUSIONS}

Anaplasmosis is a disease caused by the bacteria of the Anaplasma genus. They affect a variety of host species with varying prevalences around the world. The explanation for the variability can be the size of the population tested, the density of ticks and reservoir hosts which usually depend on the geographical area and climate, and the different strains of Anaplasma spp. that are present. To fully understand how this is all connected and to be able to conduct proper preventive measures, more research is needed on anaplasmosis caused by the different Anaplasma spp.

\section{ACKNOWLEDGEMENT}

This study was supported by IGA UVLF 04/2018 and by the Ministry of Education, Science, Research and Sport of the Slovak Republic through the contract KEGA 014UVLF4/2019.

\section{REFERENCES}

1. Aiello, S. E., Moses, M. A., 2017: The Merck Veterinary Manual. 11th edn., Merck and Co., Inc., Kenilworth, NJ, $3326 \mathrm{pp}$.

2. Aktas, M., Özübek, S., 2017: Outbreak of anaplasmosis associated with novel genetic variants of Anaplasma marginale in dairy cattle. Comp. Immunol. Microbiol. Inf. Dis., 54, 20-26. DOI: 10.1016/j.cimid.2017.07.008.

3. Alberti, A., Zobba, R., Chessa, B., Addis, M. F., Sparagano, O., Parpaglia, M. L. P., et al., 2005: Equine and canine Anaplasma phagocytophilum strains isolated on the island of Sardinia (Italy) are phylogenetically related to pathogenic strains from the United States. Appl. Envir. Microbiol., 71, 10, 6418-6422. DOI: 10.1128/AEM.71.10.6418-6422.2005.

4. Ammustagui, I., Sainz, Á., Tesouro, M. Á., 2006: Serological evaluation of Anaplasma phagocytophilum infection in livestock in Northwestern Spain. Ann. New York Acad. Sci., 1078, 487-490. DOI: 10.1196/annals.1374.091.

5. Battilani, M., Arcangeli, S. D., Balboni, A., Dondi, F., 2017: Genetic diversity and molecular epidemiology of Anaplasma. Infect. Genet. Evol., 49, 195-211. DOI: 10.1016/j.meegid.2017.01.021.

6. Baumgartner, W., Schlerka, G., Fumicz, M., Stöger, J., Awad-Masalmeh, M., Schuller, W., et al., 1992: Seroprevalence survey for Anaplasma marginale-infection of Austrian cattle. J. Vet. Med., Series B, 39, 97-104. DOI: 10.1111/ j.1439-0450.1992.tb01143.x.

7. Belkahia, H., Said, M. B., Alberti, A., Abdi, K., Issaoui, Z., Hattab, D., et al., 2015: First molecular survey and novel genetic variants' identification of Anaplasma marginale, A. centrale and A. bovis in cattle from Tunisia. Infect. Genet. Evol., 34, 361-371. DOI: 10.1016/j.meegid.2015.06.017.

8. Ben Said, M., Belkahia, H., Messadi, L., 2018: Anaplasma spp. in North Africa: A review on molecular epidemiology, associated risk factors and genetic characteristics. Ticks and Tick-Borne Dis., 9, 3, 543-_555. DOI: 10.1016/j.ttbdis. 2018.01.003. 
9. CDC, 2019: Anaplasmosis: Epidemiology and Statistics. Retrieved March 29, 2019, from Centers of Disease Control and Prevention: https://www.cdc.gov/anaplasmosis/stats/index. html.

10. Chae, J. S., Heo, E. J., Park, J. H., Choi, K. S., Dumler, J. S., Lee, S. S., et al., 2009: Detection of antibodies reacting with Anaplasma phagocytophilum and Ehrlichia chaffeensis from cats, horses and cattle in Korea. J. Vet. Clin., 26, 6, 515-519. DOI: $10.3347 / \mathrm{kjp} .2018 .56 .3 .287$

11. Chilton, N. B., Dergousoff S. J., Lysyk, T. J., 2018: Prevalence of Anaplasma bovis in Canadian population of the Rocky Mountain wood tick, Dermacentor andersoni. Ticks and Tick-Borne Dis., 9, 6, 1528-1531. DOI: 10.1016/j.ttbdis. 2018.07.003.

12. Cui, Y., Yan, Y., Wang, X., Cao, S., Zhang, Y., Jian, F., et al., 2017: First molecular evidence of mixed infections of Anaplasma species in dogs in Henan, China. Ticks and TickBorne Dis., 8, 2, 283-289. DOI: 10.1016/j.ttbdis.2016.12.001.

13. Dahmani, M., Marié, J., Scandola, P., Brah, S., Davoust, B., Mediannikov, O., 2017: Anaplasma ovis infects sheep in Niger. Small Rumin. Res., 151, 32-35. DOI: 10.1016/j.smallrumres.2017.04.012.

14. Derdáková, M., Štefančíková, A., Špitalská, E., Taragelová, V., Koštálová, T., Hrkl’ová, G., et al., 2011: Emergence and genetic variability of Anaplasma species in small ruminants and ticks from Central Europe. Vet. Microbiol., 153, 293-298. DOI: 10.1016/j.vetmic.2011.05.044.

15. Dewage, B. G., Little, S., Payton, M., Beall, M., Braff, J., Szlosek, D., et al., 2019: Trends in canine seroprevalence to Borrelia burgdorferi and Anaplasma spp. in the eastern USA, 2010-2017. Parasit. Vectors, 12, 1, 476. DOI: 10.1186/s13071019-3735-x.

16. dos Santos, T. M., Roier, E. C. R., Pires, M. S., Santos, H. A., Vilela, J. A. R., Peckle, M., et al., 2019: Molecular evidence of Anaplasma phagocytophilum and Theileria equi coinfection in horses from Rio de Janeiro, Brazil. Vet. Anim. Sci., 7, 1-5. DOI: 10.1016/j.vas.2019.100055.

17. Dumler, J. S., Barbet, A. F., Bekker, C. P., Dasch, G. A., Palmer, G. H., Ray, S. C., et al. 2001: Reorganization of genera in the families Rickettsiaceae and Anaplasmataceae in the order Rickettsiales: unification of some species of Ehrlichia equi with Anaplasma, Cowdria with Ehrlichia and Ehrlichia with Neorickettsia, description of six new species combinations and designation of Ehrlichia equi and "HGE agent" as subjective synonyms of Ehrlichia phagocytophila. Int. J. Syst. Evol. Microbiol., 51, 6, 2145-2165. DOI: 10.1099/00207713-51-6-2145.
18. Dziegel, B., Adaszek, L., Kalinowski, M., Winiarczyk, S., 2013: Equine granulocytic anaplasmosis. Res. Vet. Sci., 95, 2, 316-320. DOI: 10.1016/j.rvsc.2013.05.010.

19. Ebani, V., Cerri, D., Fratini, F., Ampola, M., Andreani, E., 2008: Seroprevalence of Anaplasma phagocytophilum in domestic and wild animals from central Italy. New Microbiol., 31, 371-375.

20. Ebani, V. V., Nardoni, S., Bertelloni, F., Rocchigiani, G., Mancianti F., 2015: Tick-borne infections in horses from Tuscany, Italy. J. Equine Vet. Sci., 35, 4, 290-294. DOI: 10.1016/ j.jevs.2015.01.017.

21. Ebani, V. V., 2019: Serological evidence of Anaplasma phagocytophilum and spotted fever group Rickettsia spp. exposure in horses from Central Italy. Pathogens, 8, 88, 1-8. DOI: 10. 3390/pathogens 8030088 .

22. Enkhataivan, B., Narantsatsral, S., Davaasuren, B., Otgonsuren, D., Amgalanbaatar, T., Uuganbayar E., et al., 2019: Molecular detection of Anaplasma ovis in small ruminants and ixodid ticks from Mongolia. Parasitol. Int., 69, 47-53. DOI: 10.1016/j.parint.2018.11.004.

23. Farkas, R., Gyurkovsky, M., Lukács, Z., Aladics, B., Solymosi, N., 2014: Seroprevalence of some vector-borne infections of dogs in Hungary. Vector Borne Zoonotic Dis., 14, 4, 256-260. DOI: 10.1089/vbz.2013.1469.

24. Flåttsenteret, 2019: Anaplasmose_Veilederfor Helsepersonell. Retrieved March 28,2019, from Norwegian National Centrefor Tick-borne Diseases: https://xn-flttsenteret-ucb.no/sykdom mer-og-symptomer/sykdommer/anaplasmose/.

25. Foley, J. E., Nieto, C. N., Adjemian, J., Dabritz, H., Brown, R. N., 2008: Anaplasma phagocytophilum infection in small mammal hosts of Ixodes ticks, western United States. Emerg. Infect. Dis., 14, 7, 1147-1150. DOI:10.3201/eid1407.071599.

26. Fourie, J. J., Evans, A., Labuschagne, M., Crafford, D., Madder, M., Pollmeier, M., et al., 2019: Transmission of Anaplasma phagocytophilum (Foggie, 1949) by Ixodes ricinus (Linnaeus, 1758) ticks feeding on dogs and artificial membranes. Parasit. Vectors, 12, 136. DOI: 10.1186/s13071-0193396-9.

27. Galemore, E. R., Labato, M. A., O’Neil, E., 2018: Prevalence of Anaplasma phagocytophilum infection in feral cats in Massachusetts. J. Feline Med. Surg. Open Rep., 1-6, 4, 1. DOI: $10.1177 / 2055116917753804$.

28. Gofton, A. W., Waudby, H. P., Petit, S., Greay, T. L., Ryan, U. M., Irwin, P. J., 2017: Detection and phylogenetic characterization of novel Anaplasma and Erlichia species in Amblyomma triguttatum subsp. from four allopatric popula- 
tions in Australia. Ticks and Tick-Borne Dis., 8, 5, 749-756. DOI: 10.1016/j.ttbdis.2017.05.009.

29. Grandi, G., Aspán, A., Pihl, J., Gustafsson, K., Engström, F., Jinnerot, T., et al., 2018: Detection of tick-borne pathogens in lambs undergoing prophylactic treatment against ticks on two Swedish farms. Front. Vet. Sci., 5, 73, 1-6. DOI: 10.3389/ fvets.2018.00072.

30. Greene, C. E., 2012: Infectious Diseases of the Dog and Cat. 4th edn., Elsevier Inc., St. Louis, MO, 1345 pp.

31. Henningsson, A. J., Hvidsten, D., Kristiansen, B., Matussek, A., Stuen, S., Jenkins, A., 2015: Detection of Anaplasma phagocytophilum in Ixodes ricinus ticks from Norway using a real-time PCR assay targeting the Anaplasma citrate synthase gene gltA. BMC Microbiol., 15, 153, 1-6. DOI: 10.1186/ st2866-015-0486-5.

32. Hornok, S., Sugár, L., de Mera, I. G. F., de la Fuente, J., Horváth, G., Kovács, T., et al., 2018: Tick- and fly-borne bacteria in ungulates: the prevalence of Anaplasma phagocytophilum, haemoplasmas and rickettsiae in water buffalo and deer species in Central Europe, Hungary. BMC Vet. Res., 14, 98. DOI: 10.1186/s12917-018-1403-6.

33. Hulínska, D., Langrová, K., Pejčoch, M., Pavlásek, I., 2004: Detection of Anaplasma phagocytophilum in animals by real-time polymerase chain reaction. APMIS, 112, 4-5. DOI: 10.1111/j.1600-0463.2004.apm11204-0503.x.

34. Jahfari, S., Coipan, E. C., Fonville, M., van Leeuwen, A. D., Hengeveld, P., Heylen, D., et al., 2014: Circulation of four Anaplasma phagocytophilum ecotypes in Europe. Parasit. Vectors, 7, 365, 1-11. DOI: 10.1186/1756-3305-7-365.

35. Jensen, J., Simon, D., Escobar, H. M., Soller, J. T., Bullerdiek, J., Beelitz, P., et al., 2007: Anaplasma phagocytophilum in dogs in Germany. Zoonoses and Public Health, 54, 94-101. DOI: 10.1111/j.1863-2378.2007.01028.x.

36. Kocan, K. M., de la Fuente, J., Guglielmone, A. A., Meléndez, R. D., 2003: Antigens and alternatives for control of Anaplasma marginale infection in cattle. Clin. Microbiol. Rev., 16, 4, 698-712. DOI: 10.1128/CMR.16.4.698-712.2003

37. Kocan, K. M., de la Fuente, J., Blouin, E. F., Coetzee, J. F., Ewing, S. A., 2010: The natural history of Anaplasma marginale. Vet. Parasitol., 167, 2-4, 95-107. DOI: 10.1016/j. vetpar.2009.09.012

38. Kohn, B., Silaghi, C., Galke, D., Arndt, G., Pfister, K., 2011: Infections with Anaplasma phagocytophilum in dogs in Germany. Res. Vet. Sci., 91, 1, 71-76. DOI: s10.1016/j.rvsc. 2010.08.008.

39. Li, H., Zheng, Y. C., Ma, L., Jia, N., Jiang, B. G., Jiang, R. R., et al., 2015: Human infection with a novel tick-borne Anaplasma species in China: a surveillance study. Lancet Infect. Dis., 15, 6, 663-670. DOI: 10.1016/S1473-3099(15)70051-4.

40. Mattilsynet, 2018: Forsøksdyr: Persistens-overføring av A. phagocytophilum-smitte mellom flått og sau. Retrieved March 28, 2019, from The Norwegian Food Safety Authority: https://www.mattilsynet.no/dyr_og_dyrehold/dyrevelferd/ forsoksdyr/forsoksdyrsoknader/persistens__overforing av_a_phagocytophilumsmitte_mellom_flaatt_og_sau.32342.

41. Mattilsynet, 2019: Vedlegg. C-sjukdommer. Retrieved March 28, 2019, from The Norwegian Food Safety Authority: https:// www.mattilsynet.no/dyr_og_dyrehold/dyrehelse/dyresyk dommer/csykdommer.5498/binary/C-sykdommer.

42. M'ghirbi, Y., Bèji, M., Oporto, B., Khrouf F., Hurtdao, A., Bouattour, A., 2016: Anaplasma marginale and A. phagocytophilum in cattle in Tunisia. Parasit. Vectors., 9, 1, 1-8. DOI: 10.1186/s13071-016-1840-7.

43. Milner, J. M., van Beest, F. M., 2013: Ecological correlates of a tick-borne disease, Anaplasma phagocytophilum, in moose in southern Norway. Eur. J. Wildl. Res., 59, 3, 399-406. DOI: $10.1007 / \mathrm{s} 10344-012-0685-4$.

44. Movilla, R., García, C., Siebert, S., Roura, X., 2016: Countrywide serological evaluation of canine prevalence for $A n$ aplasma spp., Borrelia burgdorferi (sensu lato), Dirofilaria immitis and Erlichia canis in Mexico. Parasit. Vectors., 9, 421. DOI: 10.1186/s13071-016-1685-Z.

45. Mullen, G. R., Durden., L. A., 2017: Medical and Veterinary Entomology. 3rd edn., Elsevier Inc., London, 769 pp.

46. Noaman, V., Shayan, P., 2010: Molecular detection of Anaplasma bovis in cattle from Central part of Iran. Vet. Res. Forum, 1, 2, 117-122.

47. Nogueira, R. M. S., Silva, A. B., Sato, T. P., de Sá, J. C., dos Santos, A. C. G., Filho, E. F. A., et al., 2017: Molecular and serological detection of Theileria equi, Babesia caballi and Anaplasma phagocytophilum in horses and ticks in Maranhão, Brazil. Pesqui. Vet. Bras., 37, 12, 1416-1422. DOI: 10.1590/ S0100-736X2017001200010.

48. Ojeda-Chi, M. M., Rodriguez-Vivas, R. I., Esteve-Gasent, M. D., León, A. P., Modarelli, J. J., Villegas-Perez, S., 2019: Molecular detection of rickettsial tick-borne agents in white-tailed deer (Odocoileus virginianus yucatanensis), Mazama deer (Mazama temama), and the ticks they host in Yucatan Mexico. Ticks and Tick-Borne Dis., 10, 2, 365-370. DOI: 10.1016/j.ttbdis.2018.11.018

49. Ola-Fadunsin, S. D., Gimba, F. I., Abdullah, D. A., Sharma, R. S. K., Abdullah, F. J. F., Sani, R. A., 2018: Epidemi- 
ology and risk factors associated with Anaplasma marginale infection of cattle in Peninsular, Malaysia. Parasitol. Int., 67, 6, 659-665. DOI: 10.1016/j.parint.2018.06.013.

50. Parham, P. E., Waldock, J., Christophides, G. K., Hemming, D., Agusto, F., Evans, K. J., et al. 2015: Climate, environmental and socio-economic change: weighing up the balance in vector-borne disease transmission. Phil. Trans. R. Soc. Lond. B Biol. Sci., 370, 1-17. DOI: 10.1098/rstb.2013.0551.

51. Passamonti, F., Veronesi, F., Cappelli, K., Capomaccio, S., Coppola, G., Marenzoni, M. L., et al., 2010: Anaplasma phagocytophilum in horses and ticks: A preliminary survey of Central Italy. Comp. Immunol. Microbiol. Infect. Dis., 33, 1, 73-83. DOI: 10.1016/j.cimid.2008.08.002.

52. Peng, Y., Wang, K., Zhao, S., Yan, Y., Wang, H., Jing, J., et al., 2018: Detection and phylogenetic characterization of Anaplasma capra: An emerging pathogen in sheep and goats in China. Front. Cell. Infect. Microbiol., 8, 283, 1-7. DOI: 10.3389/fcimb.2018.00283.

53. Praskova, I., Bezdekova, B., Zeman, P., Jahn, P., 2011: Seroprevalence of Anaplasma phagocytophilum in horses in the Czech Republic. Ticks and Tick-Borne Dis., 2, 111-115. DOI: 10.1016/j.ttbdis.2011.01.002.

54. Razanske, I., Rosef, O., Radzijevskaja, J., Bratchikov, M., Griciuviene, L., Paulauskas, A., 2019: Prevalence and co-infection with tick-borne Anaplasma phagocytophilum and Babesia spp. in red deer (Cervus elaphus) and roe deer ( $\mathrm{Ca}$ preolus capreolus) in Southern Norway. Int. J. Parasitol., 8, 127-134. DOI: 10.1016/j.ijppaw.2019.01.003.

55. Rolim, M. F., Oliveira, F. C. R., Graca, F. A. S., Brasil, F. C., 2015: Serological evidence of exposure to Anaplasma phagocytophilum in horses from the Rio de Janeiro State Mounted Police bred in the urban zone. Ciênc. Anim. Bras., 16, 3, 377-387. DOI: 10.1590/1089-6891v16i319865.

56. Salvagni, C. A., Dagnone, A. S., Gomes, T. S., Mota, J. S., Andrade, G. M., Baldani, C. D., et al., 2009: Serologic evidence of equine granulocytic anaplasmosis in horses from central West Brazil. Rev. Bras. Parasitol. Vet., 19, 3, 135-140. DOI: 10.1590/S1984-29612010000300002.

57. Schvartz, G., Epp, T., Burgess, H. J., Chilton, N. B., Pearl, D. L., Lohmann, K. L., 2015: Seroprevalence of equine granulocytic anaplasmosis and Lyme borreliosis in Canada as determined by a point-of-care enzyme-linked immunosorbent assay (ELISA). Can. Vet. J., 56, 575-580.

58. Sellon, D. C., Long, M. T., 2014: Equine Infectious Diseases. Elsevier Inc., St. Louis, MO, 650 pp.

59. Seo, M., Ouh, I. O., Lee, H., Geraldino, P. J. L., Rhee, M. H.,
Kwon, O. D., et al., 2018: Differential identification of Anaplasma in cattle and potential of cattle to serve as reservoir of Anaplasma capra, an emerging tick-borne zoonotic pathogen. Vet. Microbiol., 226, 15-22. DOI: 10.1016/j.vetmic. 2018.10.008.

60. Slivinska, K., Víchová, B., Werszko, J., Szewczyk, T., Wróblewski, Z., Petko, B., et al., 2016: Molecular surveillance of Theileria equi and Anaplasma phagocytophilum infections in horses from Ukraine, Poland and Slovakia. Vet. Parasitol., 2015, 35-37. DOI: 10.1016/j.vetpar.2015.10.025.

61. Springer, A., Montenegro, V. M., Schicht, S., Pantchev, N., Strube, C., 2018: Seroprevalence and current infections of canine vector-borne diseases in Nicaragua. Parasit. Vectors, 11, 585. DOI: 10.1186/s13071-018-3173-1.

62. Stigum, V. M., Jaarsma, R. I., Sprong, H., Rolandsen, C. M., Mysterud, A., 2019: Infection prevalence and ecotypes of Anaplasma phagocytophilum in moose Alces, red deer Cervus elaphus, roe deer Capreolus and Ixodes ricinus ticks from Norway. Parasit. Vectors, 1, 12, 1-8. DOI: 10.1186/s13071018-3256-z

63. Stuen, S., Bergström, K. 2008: Human anaplasmose-en skjult sykdom i Norge? Tidskr. Nor. Legeforen., 128, 22, 2579-2581.

64. Sykes, J. E., 2014: Canine and Feline Infectious Diseases. Elsevier Inc., St Louis, MO, 915 pp.

65. Theiler, Sir A., 1911: Further investigation into Anaplasmosis of South African cattle. 1st Report of the Director of Veterinary Research, 7-46.

66. Uminski, K., Kadkhoda, K., Houston, B. L., Lopez, A., MacKenzie, L. J., Lindsay, R., et al., 2018: Anaplasmosis: An emerging tick-borne disease of importance in Canada. IDCases, 14, 1-4, e00472. DOI: 10.1016/j.idcr.2018.e00472.

67. van der Kolk, J. H., Veldhuis Kroeze, E. J. B., 2013: Infectious Diseases of the Horse. Manson Publishing Ltd., London, $336 \mathrm{pp}$.

68. Villeneuve, A., Goring, J., Marcotte, L., Overvelde, S., 2011: Seroprevalence of Borrelia burgdorferi, Anaplasma phagocytophilum, Ehrlichia canis, and Dirofilaria immitis among dogs in Canada. Can. Vet. J., 52, 5, 527-530.

69. Yabsley, M. J., Romines, J., Nettles, V. F., 2006: Detection of Babesia and Anaplasma species in rabbits from Texas and Georgia, USA. Vector Borne Zoonotic Dis., 6, 1, 7-13. DOI: 10.1089/vbz.2006.6.7.

70. Yang, J., Liu, Z., Guan, G., Liu, Q., Li, Y., Chen, Z., et al., 2013: Prevalence of Anaplasma phagocytophilum in ruminants, rodents and ticks in Gansu, north-western Chi- 
na. J. Med. Microbiol., 62, 254-258. DOI: 10.1099/jmm. 0.046771-0.

71. Yang, J., Han, R., Niu, Q., Liu, Z., Guan, G., Liu, G., et al., 2018: Occurrence of four Anaplasma species with veterinary and public health significance in sheep, northwestern China. Ticks and Tick-Borne Dis., 9, 1, 82-85. DOI: 10.1016/j.ttbdis.2017.10.005.

72. Yousefi, A., Rahbari, S., Shayan, P., Sadeghi-dehkordi, Z., Bahonar, A., 2017: Molecular detection of Anaplasma marginale and Anaplasma ovis in sheep and goat in west highland pasture of Iran. Asian Pac. J. Trop. Biomed., 7, 5, 455-459. DOI: 10.1016/j.apjtb.2017.01.017.
73. Zhou, M., Cao, S., Sevinc, F., Sevinc, M., Ceylan, O., Ekici, S., et al., 2017: Molecular detection and genetic characterization of Babesia, Theileria and Anaplasma amongst apparently healthy sheep and goats in the central region of Turkey. Ticks and Tick-Borne Dis., 8, 2, 246-252. DOI: 10.1016/j.ttbdis. 2016.11.006.

Received July 23, 2020

Accepted September 14, 2020 